\title{
Glucagon, Insulin, and Growth Hormone Response to Exchange Transfusion in Premature and Term Infants
}

\author{
R. D. G. MILNER, M. FEKETE, and R. ASSAN \\ From the Department of Child Health, University of Manchester, and the Faculté de Medecine de Paris, France
}

\begin{abstract}
Milner, R. D. G., Fekete, M., and Assan, R. (1972). Archives of Disease in Childhood, 47, 186. Glucagon, insulin, and growth hormone response to exchange transfusion in premature and term infants. Exchange transfusions were performed on premature or term infants using blood preserved with acid citrate and glucose. The plasma concentrations of glucose, free fatty acids, insulin, glucagon, and growth hormone were measured in the donor blood and in blood from the infant at different times during the transfusion. The total amounts of metabolite and hormone infused and removed from the infant were calculated. The exchange transfusion caused a larger rise in plasma glucose of premature infants than of term infants, due in part to a higher plasma glucose in the donor blood used for premature infants. Despite the higher plasma glucose levels, the premature infants secreted less insulin in response to the glucose challenge, as judged by the rise in plasma insulin and the insulin balance. The transfusions were associated with increased growth hormone secretion in both groups. Premature infants secreted more growth hormone per kg bodyweight than term infants. Plasma glucagon levels in term and premature infants before transfusion were higher than those found in normal infants under comparable conditions. The transfusion caused a similar fall in plasma concentration and a similar negative balance of free fatty acids and glucagon in each group.
\end{abstract}

Glucagon, insulin, and growth hormone $(\mathrm{GH})$ secretion have been studied during exchange transfusions in 2 groups of infants, one term and the other premature. By careful selection of patients and attention to conditions of transfusion, it is possible to make comparisons of hormonal and metabolic interrelations between the groups which are a function of gestational age. The investigation was performed in the hope that the study of infants with hyperbilirubinaemia might yield information of a qualitative nature which could be extrapolated to the normal premature and term infant.

\section{Patients and Methods}

Two groups of infants were studied, one term, gestational age 37 weeks or more, and the other premature, gestational age 36 weeks or less. Clinical details of the groups are given in Table I. All infants were of normal birthweight for their gestational age by the criteria of Butler and Alberman (1969). Two transfusions in the premature group were performed for

Received 22 October 1971. hyperbilirubinaemia of unknown aetiology; all other transfusions were carried out for rhesus incompatibility of mild or moderate severity. Pregnancies were uneventful apart from rhesus sensitization and all infants were born spontaneously except 2 who were delivered by caesarean section for maternal reasons. One of the premature infants needed resuscitation and definite signs of cerebral damage were detected later.

Exchange transfusions were performed with blood preserved with acid citrate and dextrose $(2.0 \mathrm{~g}$ disodium citrate and $3.0 \mathrm{~g}$ dextrose dissolved in $120 \mathrm{ml}$ water) The transfusion technique was the same as that described by Milner et al. (1972). The rate of transfusion and volume exchanged were similar in the 2 groups (Table I). The collection, storage, and methods of analysis of blood samples were as described previously (Milner et al., 1972).

\section{Results}

In the donor blood used for the transfusion of term infants it happened that the mean concentration of glucose was lower $(P<0.05)$, and of insulin higher $(P<0.05)$ than in the blood used for premature infants. The mean level of all other substances which were measured was similar in 
TABLE I

Clinical Details of Infants Studied

\begin{tabular}{|c|c|c|c|c|c|c|c|c|c|c|c|c|}
\hline & \multicolumn{2}{|c|}{ Number and Sex } & \multicolumn{2}{|c|}{ Birthweight (g) } & \multicolumn{2}{|c|}{$\begin{array}{l}\text { Gestational } \\
\text { Age (wk) }\end{array}$} & \multicolumn{2}{|c|}{$\begin{array}{l}\text { Postnatal } \\
\text { Age (hr) }\end{array}$} & \multicolumn{2}{|c|}{$\begin{array}{c}\text { Rate of Exchange } \\
(\mathrm{ml} / \mathrm{min})\end{array}$} & \multicolumn{2}{|c|}{$\begin{array}{l}\text { Volume of } \\
\text { Exchange }^{\star}\end{array}$} \\
\hline & Male & Female & Mean & Range & Mean & Range & Mean & Range & Mean & Range & Mean & Range \\
\hline $\begin{array}{l}\text { Term } \\
\text { Premature }\end{array}$ & $\begin{array}{l}7 \\
7\end{array}$ & $\begin{array}{l}3 \\
2\end{array}$ & $\begin{array}{l}3144 \\
2024\end{array}$ & $\begin{array}{l}2550-4020 \\
1100-2680\end{array}$ & $\begin{array}{l}38 \\
34\end{array}$ & $\begin{array}{l}37-39 \\
27-36\end{array}$ & $\begin{array}{l}35 \\
31\end{array}$ & $\begin{array}{l}8-93 \\
5-108\end{array}$ & $\begin{array}{l}4 \cdot 9 \\
4 \cdot 1\end{array}$ & $\begin{array}{l}3 \cdot 7-7 \cdot 3 \\
2 \cdot 8-7 \cdot 3\end{array}$ & $\begin{array}{l}1 \cdot 5 \\
1 \cdot 6\end{array}$ & $\begin{array}{l}1 \cdot 2-1 \cdot 8 \\
1 \cdot 3-1 \cdot 9\end{array}$ \\
\hline
\end{tabular}

*Calculated as: volume exchanged divided by blood volume of infant $(85 \mathrm{ml} / \mathrm{kg})$.

the donor blood used in the 2 clinical groups. No significant difference was found in the mean concentration of glucose, free fatty acids (FFA), insulin, glucagon, and $\mathrm{GH}$ between the term and premature infants at the start of the transfusion (Table II).

The plasma glucose of both groups of infants rose progressively during the transfusion due to the high plasma glucose concentration in the donor blood. The rise in plasma glucose concentration of the premature infants was greater than that of the term infants, the difference being significant from the $200 \mathrm{ml}$ point onwards (P $<0.025)$. In both groups there was a highly significant positive glucose balance $(P<0.001)$, but, due to the lower plasma glucose concentration of the donor blood in the transfusions of term infants, the amount of glucose infused in this group per $\mathrm{kg}$ body weight was less than that infused in the premature infants $(P<0.005)$. For the same reason the positive glucose balance in premature infants was greater than that in the term infants $(P<0 \cdot 025)$ (Table III).

The plasma FFA level was similar in both groups of infants at the start of the transfusion, and much higher than that in the donor blood. During the transfusions the level fell continuously. Despite the uniformity of the plasma FFA level in the donor blood and the 2 groups of infants before transfusion, the plasma FFA fell faster in the premature infants. After $200 \mathrm{ml}$ had been transfused the mean plasma FFA was lower in the premature than in the term infants $(P<0.02)$, but by the end of the transfusion there was no significant difference between the groups. In each group there was a significant and very similar negative FFA balance.

The mean plasma insulin concentration in the donor blood was fortuitously very similar to that in each group of infants at the start of the transfusion (Table II). During transfusion there was a significant rise in plasma insulin levels in both groups. The rise was greater in the term group than in the

TABLE II

Mean $( \pm S E)$ Plasma Concentration of Metabolites and Hormones During Exchange Transfusion in Term and Premature Infants

\begin{tabular}{|c|c|c|c|c|c|}
\hline Donor & $0 \mathrm{ml}$ & $100 \mathrm{ml}$ & $200 \mathrm{ml}$ & $300 \mathrm{ml}$ & $400 \mathrm{ml}$ \\
\hline $\begin{array}{cc}\text { Glucose }(\mathrm{mg} / 100 \mathrm{ml}) \\
\text { Term } & 386 \pm 35(10) \\
\text { Premature } & 480 \pm 28(10)\end{array}$ & $\begin{array}{ll}75 \pm 4 & (10) \\
62 \pm 4 & (10)\end{array}$ & $\begin{array}{l}120 \pm 3 \quad(10) \\
131 \pm 6 \quad(10)\end{array}$ & $\begin{array}{l}139 \pm 4 \quad(10) \\
166 \pm 9 \quad(10)\end{array}$ & $\begin{array}{l}153 \pm 8 \quad(10) \\
198 \pm 13 \quad(9)\end{array}$ & $\begin{array}{c}157 \pm 14(8) \\
-\end{array}$ \\
\hline $\begin{array}{cc}F F A(\mu \mathrm{mol} / l .) & \\
\text { Term } & 302 \pm 47(10) \\
\text { Premature } & 277 \pm 52(9)\end{array}$ & $\begin{array}{l}1299 \pm 155 \\
1296 \pm 204\end{array}$ & $\begin{array}{l}983 \pm 80(10) \\
778 \pm 73\end{array}$ & $\begin{array}{l}817 \pm 72(10) \\
573 \pm 58\end{array}$ & $\begin{array}{l}596 \pm 70(10) \\
450 \pm 49\end{array}$ & $\begin{array}{c}503 \pm 70(8) \\
-\end{array}$ \\
\hline $\begin{array}{ccc}\text { Insulin }(\mu U / m l) & \\
\text { Term } & 37 \pm 6 & (10) \\
\text { Premature } & 20 \pm 2 & (10)\end{array}$ & $\begin{array}{ll}34 \pm 6 & (10) \\
24 \pm 4 & (10)\end{array}$ & $\begin{array}{l}64 \pm 17(10) \\
37 \pm 6 \quad(10)\end{array}$ & $\begin{array}{l}63 \pm 10(10) \\
42 \pm 7 \quad(10)\end{array}$ & $\begin{array}{l}74 \pm 17(10) \\
40 \pm 4\end{array}$ & ${ }^{81 \pm 15(8)}$ \\
\hline $\begin{array}{ll}\text { Glucagon }(p g / m l) \\
\text { Term } & 282 \pm 29(10) \\
\text { Premature } & 275 \pm 51\end{array}$ & $\begin{array}{l}513 \pm 80 \\
613 \pm 172\end{array}$ & $\begin{array}{l}433 \pm 62(10) \\
470 \pm 55 \text { (8) }\end{array}$ & $\begin{array}{l}423 \pm 62(10) \\
368 \pm 32\end{array}$ & $\begin{array}{l}410 \pm 54(10) \\
338 \pm 39(7)\end{array}$ & $\begin{array}{c}377 \pm 36(8) \\
-\end{array}$ \\
\hline $\begin{array}{cc}\text { Growth hormone } & (\mathrm{ng} / \mathrm{ml}) \\
\text { Term } & 3 \pm 0 \cdot 7(10) \\
\text { Premature } & 2 \pm 0 \cdot 3(10)\end{array}$ & $\begin{array}{ll}29 \pm 4 & (10) \\
32 \pm 5 & (10)\end{array}$ & $\begin{array}{ll}45 \pm 8 & (10) \\
55 \pm 9 & (10)\end{array}$ & $\begin{array}{l}58 \pm 9(10) \\
99 \pm 15(10)\end{array}$ & $\begin{array}{r}84 \pm 16(10) \\
134 \pm 26(9)\end{array}$ & $94 \pm 31(8)$ \\
\hline
\end{tabular}

Number of observations shown in parentheses. 
TABLE III

Amounts $( \pm S E)$ of Metabolites and Hormones Infused and Removed in Exchange Transfusions in Term and Premature Infants

\begin{tabular}{|c|c|c|}
\hline Metabolite or Hormone & In/kg body weight & Out/kg body weight \\
\hline $\begin{array}{c}\text { Glucose }(m g) \\
\text { Term } \\
\text { Premature }\end{array}$ & $\begin{array}{l}217 \pm 22 \\
348 \pm 32\end{array}$ & $\begin{array}{l}100 \pm 7^{\star} \\
142 \pm 18^{\star}\end{array}$ \\
\hline $\begin{array}{c}F F A(\mu m o l) \\
\text { Term } \\
\text { Premature }\end{array}$ & $\begin{array}{l}16 \pm 2 \\
23 \pm 6\end{array}$ & $\begin{array}{l}61 \pm 6^{\star} \\
68 \pm 11 \dagger\end{array}$ \\
\hline $\begin{array}{c}\text { Insulin }(m U) \\
\text { Term } \\
\text { Premature }\end{array}$ & $\begin{array}{l}1 \cdot 91 \pm 0 \cdot 42 \\
1 \cdot 55 \pm 0 \cdot 25\end{array}$ & $\begin{array}{l}4 \cdot 33 \pm 0 \cdot 70 \dagger(10) \\
3 \cdot 67 \pm 0 \cdot 83 \pm(10)\end{array}$ \\
\hline $\begin{array}{c}\text { Glucagon }(n g) \\
\text { Term } \\
\text { Premature }\end{array}$ & $\begin{array}{l}16 \cdot 4 \pm 2 \cdot 1 \\
22 \cdot 6 \pm 5 \cdot 0\end{array}$ & $\begin{array}{l}29 \cdot 2 \pm 4 \cdot 4 \ddagger \quad(10) \\
39 \cdot 1 \pm 8 \cdot 6 \quad(8)\end{array}$ \\
\hline $\begin{array}{l}\text { Growth Hormone }(\mu g) \\
\text { Term } \\
\text { Premature }\end{array}$ & $\begin{array}{l}0 \cdot 21 \pm 0 \cdot 05 \\
0 \cdot 18 \pm 0 \cdot 04\end{array}$ & $\begin{array}{l}4 \cdot 57 \pm 0 \cdot 68^{\star}(10) \\
7 \cdot 39 \pm 1 \cdot 22^{\star}(10)\end{array}$ \\
\hline
\end{tabular}

The number of observations are shown in parentheses.

Level of significance: ${ }^{\star} P<0.001,+P<0.01, \pm P<0.05$, for comparison of amount removed against amount infused.

premature group $(P<0.05)$. A similar and significantly negative insulin balance occurred in both groups (Table III).

In both groups a progressive and large rise in plasma GH levels occurred during exchange transfusion, despite the much lower plasma GH levels in the donor blood than in the infants before transfusion. The mean rise of plasma $\mathrm{GH}$ in the premature group was $90 \pm 21 \mathrm{ng} / \mathrm{ml}$ which was greater than that occurring in the term group, $68 \pm 26 \mathrm{ng} / \mathrm{ml}(\mathrm{P}<0.05)$. A highly significant negative balance of growth hormone occurred in each group. This was $7 \cdot 2 \pm 1 \cdot 2 \mu \mathrm{g} / \mathrm{kg}$ in the premature group which was not significantly greater than the net loss of $\mathrm{GH}$ in the term group, $4 \cdot 36 \pm 0 \cdot 69 \mu \mathrm{g} / \mathrm{kg}$.

The plasma glucagon level in the donor blood was lower than that in the infants before transfusion. During transfusion there was a gradual, progressive fall in plasma glucagon levels in each group. There was a negative glucagon balance in each group which was significant in the term infants, but larger and more variable in the premature infants.

\section{Discussion}

The purpose of this investigation was to use exchange transfusions as a tool to study the effect of gestational age on the secretion of insulin, glucagon, and growth hormone. Previous work has shown that during exchange transfusions using blood preserved with acid citrate and glucose there is increased secretion of insulin and growth hormone (Milner et al., 1972). Though infants undergoing exchange transfusion are abnormal because they are hyperbilirubinaemic and usually suffer from erythroblastosis fetalis, it is possible, by careful selection, to pick 2 groups which are comparable in all respects except for the chosen variable: gestational age. In the present study all but 2 premature infants suffered from rhesus incompatibility. The 2 premature infants with hyperbilirubinaemia of unknown aetiology were included for analysis because the measurements in these 2 were characteristic of those in the premature group as a whole. The other important uncontrolled difference between the 2 groups was that the donor blood for the term infants had significantly lower plasma glucose concentration than that for the premature group. In one respect the difference in the donor blood glucose was a disadvantage, since it was a possible cause of increased GH secretion in the premature group. In another respect the higher donor blood glucose of the premature group was an advantage, since it emphasized the lower insulin secretion occurring in premature infants in response to hyperglycaemia.

The results of the investigation show that premature infants secrete more growth hormone and less insulin during exchange transfusion than term infants. No difference between the 2 groups was detected in glucagon secretion.

It may be assumed that during exchange transfusion the stimulus to insulin secretion is the 


\section{Glucagon, Insulin, and Growth Hormone Response to Exchange Transfusion in Infants}

glucose in the donor blood. Despite the premature infants receiving a larger glucose load and having thereby higher plasma glucose levels, they secreted less insulin. It is permissible to speak of insulin secretion since the mean plasma insulin level in the donor blood was similar to that of the infant before transfusion in each group, a similar negative insulin balance occurred in each group, and the rise in plasma insulin concentration in the term infants was approximately twice that in the premature group. Though many authors have suggested that the capacity of the term infant to secrete insulin is greater than that of the premature infant, this study is, as far as we can tell, the first direct demonstration of the fact.

A significantly greater rise in plasma GH levels occurred during the transfusion of premature infants than of term infants. This, coupled with the larger negative balance of $\mathrm{GH}$ in the premature group, indicated that premature infants secreted more GH than term infants during the transfusion. The increased plasma glucose levels in the premature group were not thought to be the main cause of increased GH secretion, as exchange transfusions in small-for-dates infants producing hyperglycaemia similar to that seen in the premature had caused an increase in GH secretion similar to that observed in the term group (Milner et al., 1972). Since the gestational age of the small-for-dates infants was the same as that of the term group, and the body weight similar to that of the premature group, it is apparent that the GH response is more a function of gestational age than body weight. It is known that the increased GH secretion in exchange transfusions is due, in part, to the presence of glucose in the donor blood and, in part, to other factors (Milner et al., 1972). It is not known to what degree the increased secretion of $\mathrm{GH}$ in premature infants undergoing exchange transfusion may be the result of the procedure being more stressful to the premature infant.

The plasma glucagon levels and the glucagon balance were similar in the term and premature infants. No effect of gestational age on glucagon secretion during exchange transfusion was detected.
An interesting difference in the plasma concentration of glucagon was noted when the pre-exchange plasma levels of all term and premature infants studied were compared with the measurements made on normal infants under comparable conditions (Fekete et al., 1972). The mean ( \pm SE) plasma glucagon level in 23 term infants before exchange transfusion was $605 \pm 75 \mathrm{pg} / \mathrm{ml}$ and in 9 normal term infants was $355 \pm 47 \mathrm{pg} / \mathrm{ml}$. In 8 rhesus affected premature infants before transfusion the mean $( \pm$ SE) plasma glucagon was $613 \pm 172 \mathrm{pg} /$ $\mathrm{ml}$ and in 12 premature infants who were otherwise normal the level was $390 \pm 63 \mathrm{pg} / \mathrm{ml}$. The significance of high plasma glucagon levels in rhesus affected infants is not clear.

Detailed comparisons of hormonal and metabolic changes during exchange transfusion with blood preserved with acid citrate and glucose in term normal-for-dates, term small-for-dates, and premature infants have not been presented in this paper and its companion paper (Milner et al., 1972) for the sake of clarity. The term normal-for-dates group of infants is common to both studies and therefore further comparisons may be made between appropriate groups.

We thank Professors J. A. Davis, J. Mestyán, and M. Derot for their encouragement; the Medical Research Council, the British Diabetic Association, the Research Grants Committee of the United Manchester Hospitals, and l'Institut National de la Santé et de la Recherche médicale for financial assistance; and the Royal Society for a travel grant (R.D.G.M.) in support of this study. M.F. was a Wellcome Trust Clinical Research Fellow.

REFERENCES

Butler, N. R., and Alberman, E. D. (Editors) (1969). Perinatal Problems, p. 331. Livingstone, Edinburgh.

Fekete, M., Soltész, Gy., Assan, R., and Mestyán, J. (1972). Plasma glucagon, thyrotropin, growth hormone and insulin response to cold exposure in the human newborn. Acta Paediatrica Scandinavica. (To be published.)

Milner, R. D. G., Fekete, M., Assan, R., and Hodge, J. S. (1972). Effect of glucose on plasma glucagon, growth hormone, and insulin in exchange transfusion. Archives of Disease in Childhood, 47, 179.

Correspondence to Dr. R. D. G. Milner, St. Mary's Hospital, Hathersage Road, Manchester M13 0JH. 